\title{
EHMTI-0128. Headache as an initial symptom with the patients treated at the intensive care unit of the Clinic of Neurology $1997-2013$
}

\author{
N Vukasinovic ${ }^{1 *}$ S Jolic ${ }^{1}$, V Milosevic ${ }^{1}$, M Zivkovic ${ }^{1}$, P Slankamenac $^{2}$ \\ From 4th European Headache and Migraine Trust International Congress: EHMTIC 2014 \\ Copenhagen, Denmark. 18-21 September 2014
}

\section{Introduction}

At the intensive care unit of the Clinic of Neurology of the Clinical centre Nis, within the period 1997 - 2013 6852 patients were treated, of which 4941 patient $(72,11 \%)$ with cerebrovascular diseases. $2237(45,2 \%)$ had headache as an initial symptom.

\section{Material and methods}

The database of the hospitalized patients who suffered from headache as an initial symptom (verified with imaging techniques CT and MRI) of the Clinic of neurology at the Intensive care unit was analyzed.

4941 patient (2750 men s.55,7\% and 2191 women s.44, $3 \%$ ) average age $63,11(\mathrm{SD} 0,117)$ years, $62,52+/-11,884$ years for men $63,84+/-13,068$ years for women. With TIA diagnose $132(4,8 \%)$ men and $104(4,7 \%)$ women were treated with headache $29(12,2 \%)$, with subarachnoid haemorrhage $163(5,9 \%)$ men and $257(11,7 \%)$ women, with headache $346(82,3 \%)$, with the diagnose of intracerebral hemorrhage $758(27,6 \%)$ men and $561(25,6 \%)$ women, with headache $846(64,2 \%)$. Diagnosed with ischaemic brain stroke 1360 (49,5\%) men and 978 (44, $6 \%)$ women, with headache $893(38,2 \%)$, with the diagnose of undefined brain stroke $196(7,1 \%)$ men and 160 (7, 3\%) women, with headache 123 (34, 7\%) and with the diagnose of sequel conditions after the brain stroke 141 (5, $1 \%)$ men and $131(6,0 \%)$ women, without headache.

\section{Conclusion}

There is no significant difference of the presence of headaches as initial symptom according to sex. There is a frequency of headaches with ischaemic brain stroke

${ }^{1}$ Dept.of Neurology, Clinical center Nis, Nis, Serbia

Full list of author information is available at the end of the article
(893 patients, that is $39,9 \%$ of all headaches) contrary to the expectations.

\section{Authors' details}

'Dept.of Neurology, Clinical center Nis, Nis, Serbia. ${ }^{2}$ Dept.of Neurology, Clinical center Vojvodina, Novi Sad, Serbia.

Published: 18 September 2014

doi:10.1186/1129-2377-15-S1-D75

Cite this article as: Vukasinovic et al:. EHMTI-0128. Headache as an initial symptom with the patients treated at the intensive care unit of the Clinic of Neurology 1997 - 2013. The Journal of Headache and Pain 2014 15(Suppl 1):D75.

\section{SpringerOpen ${ }^{\circ}$}

(C) 2014 Vukasinovic et al; licensee Springer. This is an Open Access article distributed under the terms of the Creative Commons Attribution License (http://creativecommons.org/licenses/by/2.0), which permits unrestricted use, distribution, and reproduction in any medium, provided the original work is properly cited.
Submit your manuscript to a SpringerOpen ${ }^{\circ}$ journal and benefit from:

- Convenient online submission

- Rigorous peer review

- Immediate publication on acceptance

- Open access: articles freely available online

- High visibility within the field

- Retaining the copyright to your article

Submit your next manuscript at $>$ springeropen.com 